\title{
A arqueologia do projeto gráfico e os modos de subjetivação na arte de Rafael Sanzio
}

\section{The archeology of visual design and modes of subjectification in the art of Rafael Sanzio}

\begin{abstract}
Resumo: A disputa por espaço comercial nas diversas mídias, o desenvolvimento de sítios eletrônicos atraentes, entre outras atividades, exige compreender como se desenvolve o arranjo de imagens que potencialmente afetem o sujeito a partir da construção de individualidades. Nos últimos 50 anos, psicologia, neurologia e tecnologia vem se aliando nessa direção, em estudos como os do movimento dos olhos e do comportamento pupilar, entre outros. Por outro lado, é possível que a busca por compreender a percepção humana com a finalidade de conduzir o olhar do espectador não se restrinja aos nossos dias. Este artigo pretende lançar um olhar sobre uma das mais importantes obras de Rafael Sanzio: A Transfiguração. Nosso objetivo é demonstrar que as metodologias em projeto gráfico atuais já eram praticadas no século XVI, pelo menos, por este renomado artista.
\end{abstract}

Palavras-chave: Arte. Cognição. Filosofia. Subjetivação. Individuação.

Abstract: The dispute for commercial space in the different forms of media, the development of attractive digital sites, among other activities, demands an understanding of how to develop the arrangement of images with the potential to affect subjects based on the construction of individuality. Over the last fifty years, psychology, neurology and technology have been working together in this direction, with studies, such as those on the eyes and pupil behavior, among others. On the other hand, it is possible that the search to understand human perception so as to better guide the viewer's gaze is not restricted to the present day. This article intends to take a look at one of Rafael Sanzio's most important works: Transfiguration. Our objective is to demonstrate that the methods in current visual design were already being practiced in the sixteenth century, at least, by this renowned artist.

Keywords: Art, Cognition. Philosophy. Subjectification. Individuation.

MENDONÇA, André Noronha Furtado de; FONSECA, Tania Mara Galli. A arqueologia do projeto gráfico e os modos de subjetivação na arte de Rafael Sanzio. Informática na Educação: teoria e prática, Porto Alegre, v. 16, n. 2, p. 147167, jul./dez. 2013.

\author{
André Noronha Furtado de Mendonça \\ Tania Mara Galli Fonseca \\ Universidade Federal do Rio Grande do Sul
}

\section{Introdução}

A comunicação pode ser considerada como uma das mais importantes características de nossa sociedade. Somos criaturas cognitivas, ou seja, percebemos e interpretamos conscientemente as informações apreendidas a partir da interação com o ambiente. Reconhecemos o espaço, a forma, o volume, a cor, a passagem do tempo. Nossa percepção é sensorial e motora, é afetiva e cognitiva. Para desenvolvermos um veículo de comunicação que se diferencie, é importante que o projetista ultrapasse os limites de seu conhecimento técnico sobre a forma e organização, absorvendo conhecimentos que o habilitem a compreender como produzir imagens capazes de afetar subjetivamente.

Pretendemos demonstrar que o amadurecimento metodológico no desenvolvimento de uma peça comercial, publicitária ou de design, não é propriedade de nosso tempo e pode ser 
identificado, de forma precursora, na obra de Rafael Sanzio. Pretendemos construir o conceito de que o que vemos, como produção de imagens, é efeito de um complexo processo intencional de fabricação de modos de subjetividade.

Desenvolveremos uma revisão pela abordagem construtiva do espaço e da forma, pela teoria da cor. Analisaremos também aspectos importantes na construção do sujeito, relacionados à percepção, comunicação, informação, memória e individuação. Na última parte, tentaremos demonstrar que o pintor renascentista Rafael Sanzio já aplicava tais conhecimentos para atingir a sensibilidade do seu público-alvo.

\section{A organização do espaço}

A geometrização do espaço não se restringe a um campo do conhecimento, a uma atividade ou era. Podemos identificar historicamente o surgimento do design como disciplina acadêmica, mas não é tarefa simples pontuar o início de cada atividade prática descrita em métodos de projeto. Por exemplo, Meggs e Purvis (2009) apresentam o projeto editorial do período renascentista já manifestando o interesse pelo arranjo geométrico espacial e pela tipografia, ou seja, podemos identificar muitas das práticas do que hoje consideramos como representativo na metodologia em design. De fato, Meggs e Purvis (2009) demonstram que o uso de redes no projeto de tipos remonta o século XV.

Considerando a tela como um plano bidimensional, intuímos que este suporte apresenta uma largura e uma altura. Suas relações dimensionais são variáveis segundo a disposição do suporte (vertical ou horizontal). Podemos definir seu centro geométrico pelo cruzamento de diagonais ou dos eixos centrais. Para Ostrowner (1983) o suporte possui um centro ótico ou perceptivo, situado pouco acima do centro geométrico. Quanto mais vertical for o suporte, maior será o deslocamento do centro perceptivo. Podemos considerar, então, o centro perceptivo como o primeiro ponto de atenção no espaço representacional. Os eixos centrais podem ser entendidos como subdivisões do espaço que podemos identificar como quadrantes. Tais quadrantes indicam simetria na divisão do espaço, e esta simetria possui desdobramentos como o conceito de espelhamento descrito por Wong (1998). Novas subdivisões podem ser projetadas, novas diagonais podem ser desenvolvidas e no cruzamento dessas, novos pontos de atenção podem surgir, gerando movimento e ritmo.

Segundo Ostrowner (1983), a organização do espaço está presente em toda a história da arte. A autora analisa a arte antiga, clássica e contemporânea, discutindo a geometrização do espaço como na aplicação da proporção áurea. ${ }^{1}$ Elam (2001) e Doczi (1981) apresentaram abordagens semelhantes. Doczi identifica, por exemplo, a proporção áurea no projeto arquitetônico de pirâmides no Egito e no México, além de sua aplicação nos eixos centrais das colunas de Stonehenge (3100 a 1100 a.C.). Doczi (1981) ilustra a geometrização do espaço na arquitetura, escultura, pintura, escrita e na representação pictórica. Segundo Doczi (1981), um dos primeiros textos documentando o uso da proporção áurea é do arquiteto romano do século I, Marcus Vitruvius Pollio.

\footnotetext{
Segundo OSTROWER (1991), existem diversos tipos de proporções, porém, uma se difere no procedimento de sua divisão, não sendo estática ou excessivamente dinâmica. Os assírios e egípcios acreditavam que esta relação era sagrada. No Renascimento, passou a ser conhecida como Divina Proporção, Seção Aurea, ou Corte de Ouro.
} 
Segundo Vitruvius, para que os templos fossem magnificentes, deveriam ser construídos em analogia ao corpo humano bem formado, com harmonia perfeita entre as partes (DOCZI, 1981).

Leonardo Da Vinci se baseou em Vitruvius para desenvolver seu diagrama conhecido como Homem Vitruviano (1490). ${ }^{2}$ "Homem Vitruviano representa a forma humana em um estado de perfeição física" (catálogo da exposição Leonardo Da Vinci, a exibição de um gênio, 2007).

Elam (2001), apresenta gráficos das preferências de consumidores por retângulos, propostos por Fechner (1876) e por Lalo (1908). Elam (2001), relata que Fechner (1876) identificou preferências cognitivas pela seção áurea estudando as características estéticas de retângulos e demonstrou que suas relações sempre estavam próximas à proporção áurea. Fechner foi posteriormente confirmado por Lalo (1908). Elam (2001) e Doczi (1981) ressaltam que a proporção áurea também se manifesta nas relações geométricas das estruturas que formam os organismos vivos. Dabner (2006), Haslam (2007), Bringhurst (2008) e Tondreau (2009) são pesquisadores do projeto editorial e tipográfico que estudam o emprego da seção áurea.

A necessidade de organizar o espaço proporcionou o desenvolvimento de princípios de construção da forma, como enumerados por Wong (1998). Entre eles: simetria, repetição, rotação, concentração, entre tantos outros. Cada princípio pode ser aplicado na unidade ou em conjunto, que, quando forma um padrão organizacional compreende um sistema de rede.

\footnotetext{
2 O desenvolvimento do Homem Vitruviano por Leonardo Da Vinci ocorre no início do período em que ele viveu em Florença, e antecede a época em que Rafael Sanzio se estabeleceu na mesma região.
}

Assim como na natureza, os sistemas de ordem regem o crescimento e a estrutura do material animado e inanimado, assim também a atividade humana está, ela mesma, desde os primeiros tempos, marcada pela busca duma ordem. Mesmo os povos mais antigos, nas suas criações, usaram formas matemáticas e adornos de grande beleza. [...] (LE CORBUSIER, apud BROCKMANN, 1982) [Tradução do autor].

Esta definição traz duas abordagens simultâneas: a natureza biológica e humana da organização espacial. Para Brockmann (1982), trabalhar com sistemas de redes significa submeter-se a leis universais:

- Sistematizar;

- Chegar ao essencial;

- Cultivar a objetividade;

- Racionalizar processos criativos e técnicos;

- Rentabilizar;

- Integrar cor, forma e material;

- Dominar o arquitetural sobre a superfície e o espaço;

- Ser positivo para o futuro.

Entendida como um sistema de controle, a rede torna mais fácil dar à superfície ou espaço uma organização funcional (BROCKMANN, 1982) [Tradução do autor].

O uso de redes na geometrização espacial é a linguagem de acoplamento entre o espaço e a forma.

\section{A forma}

Ostrowner, Wong e Munari dedicaram estudos sobre o significado da forma mas abordagens distintas. Enquanto Wong privilegia uma análise geométrica, Ostrowner irá investigar 
aspectos perceptíveis e sensíveis. Munari será intermediário em suas observações. Por enfatizaremos fatores afetivos relacionados ao desenvolvimento da forma, seguiremos nosso desenvolvimento pela abordagem de Ostrowner. Destacamos, porém, conceitos apresentados por Wong (1998), definindo três elementos práticos da forma:

- Representação - a forma deriva de algo real;

- Significado - a forma transporta uma mensagem;

- Função - a forma possui determinado propósito.

Segundo Ostrowner, formas artificiais saem do contexto conceitual e entram na condição de expressão única e individual, na produção e na percepção, o que se alinha com os elementos práticos de Wong. A forma no espaço assume uma dinâmica que pode ser estática ou de movimento. Ostrowner define esta dinâmica como energia da imagem.

Ostrowner enfatiza a ação humana buscando compreender a imagem no processo perceptivo, caminho convergente ao traçado por Deleuze no livro O que é a filosofia. Essa compreensão irá envolver as componentes afetivas ou inconscientes da imagem e as componentes cognitivas ou intelectuais ou conscientes da imagem. Ou seja, trata-se da potência da imagem como instrumento construtivo da subjetividade, assim como descrito por Deleuze. Ostrowner explora as associações feitas e as emoções registradas por seus alunos em exercícios de construção da imagem. Para a autora, esses aspectos são influenciados pela organização figurativa e pelos signos da imagem. Por exemplo, as relações entre a leitura ocidental e sua influência na organização das informações numa composição artística ou peça gráfica. A forma possui desdobramentos de complexi- dade que são os elementos pictóricos da imagem: o ponto, a linha e a superfície. Partindo do ponto, como célula germinativa da forma, sua sequência contínua nos traz o conceito geométrico de linha. Podemos seguir neste desenvolvimento passando pela organização da forma no plano bi e tridimensional, onde teremos os volumes. Além dos volumes, é importante observar a luz e a cor como elementos perceptivos da forma e do espaço. Para Ostrowner, a linha configura o espaço em uma direção, trazendo em si a propriedade de sugerir, no observador, uma idéia de continuidade ou monotonia ou, pelo contrário, uma idéia de fissura no espaço. A autora descreve que a linha apresenta múltiplas formas de como afetar o observador. Linhas longas e horizontais induzem lentidão. Uma sequência horizontal de linhas verticais induzem desaceleração e quebra na continuidade. Por outro lado, se tais linhas forem oblíquas, o efeito será de dinamismo. Tais experimentos fizeram a autora concluir que o cruzamento de sequências de linhas oblíquas neutralizam o dinamismo descrito anteriormente e causam um efeito de retenção ainda maior que o provocado por uma sequência horizontal de linhas verticais. Para a autora, altura e largura tendem a estabilizar a imagem, imobilizando-a. Porém, ao introduzirmos elementos como textura e sobreposição de planos, obtemos dinâmica de tensão na composição proporcionando uma noção de profundidade e simulando volume. Se o ponto, a linha e a superfície são elementos pictóricos da imagem, o volume, a luz e a cor serão elementos tridimensionais e dinâmicos da imagem. Para Ostrowner (1983), a presença de elementos pictóricos e tridimensionais na imagem trazem um elemento relacional entre o observador e o objeto representado que é a correspondência visual da perspectiva. O signi- 
ficado emocional da perspectiva é a expressão da profundidade espacial.

Ostrowner (1983) define a luz como elemento tridimensional no contraste formal entre claro e escuro. A autora enfatiza que não se pode confundir a luz como elemento de imagem com a luz como fenômeno físico. A luz é o elemento que, em contraste com a sombra, é capaz de compor o volume dos objetos. Ao explorar o desenvolvimento da forma desdobrada na superfície, a autora afirma que a geometrização do espaço e da forma trazem em si uma carga poética e emocional na composição, principalmente, pela introdução da cor.

\section{A cor}

Segundo Ostrowner a cor é um elemento capaz de provocar sensualidade à forma. Sua gradação tonal poderá imprimir na imagem uma carga de leveza ou peso, com maior agressividade ou passividade, com maior dinamismo ou estagnação. Isso significa que a cor é um elemento pictórico tridimensional que traz para a percepção uma grande energia emocional, sendo capaz de alterar a projeção de elementos gráficos para dentro ou para fora do plano da imagem observada.

Fraser e Banks (2007) descrevem a natureza física e emocional da cor e sua influência na percepção humana. Os autores revisam este tema e suas abordagens ao longo da história.

A teoria da cor traz para a produção publicitária, gráfica e de produto, conhecimentos acoplados com princípios e enfoques ergonômicos de projeto $^{3}$, em termos de percepção, apreensão e compreensão de significados.

De acordo com Fraser e Banks (2007) e Fa-

\footnotetext{
${ }^{3}$ Moraes \& Mont'Alvão (2010) definem enfoques ergonômicos de projeto: interfaciais, informacionais, cognitivos, organizacionais e instrucionais, entre outros.
}

rina et al. (2006), as cores possuem cargas emocionais e psicodinâmicas. Por exemplo, a cor azul inspira serenidade, introspecção, sabedoria, solidão, espaço, verdade e beleza. O azul é positivo com neutralidade psicológica. Porém, quando aplicado em determinados contextos pode assumir características negativas como insegurança, desânimo e falta de energia. A cor apresenta uma sintaxe individual. O homem reage à cor subordinado à suas condições físicas culturais. Segundo Farina et al. (2006), a sintaxe da cor rege os elementos que constituem a mensagem plástica. "As cores são a língua nativa do subconsciente" (JUNG apud FRASER; BANKS, A., 2007).

Se Jung estiver certo, a teoria da cor é forte aliada no desenvolvimento de pesquisa em ergonomia cognitiva, e por esta mesma razão, forte aliada no desenvolvimento de projetos publicitários e de design.

\section{A comunicação, a semiótica e a cognição}

Um projeto envolvendo a construção da forma contempla o cliente, o projetista e o usuário, incluindo fornecedores e distribuidores. ${ }^{4} \mathrm{O}$ projetista deve compreender como o produto se insere nesses ambientes e como este será percebido e absorvido pelo mercado. Por isso, é necessário que esse projetista desenvolva seu produto absorvendo em sua metodologia conhecimentos no campo da comunicação, semiótica e cognição. Compreenderá também aspectos do comportamento e da psicologia humana.

O sujeito se reinventa ao relacionar-se com seu mundo. Este conceito foi abordado inicialmente por Willian James em seu livro -

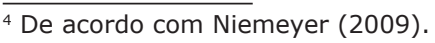


Princípios da Psicologia, que acreditava que a consciência deveria ter utilidade biológica ou não sobreviveria (apud SCHULTZ; SCHULTZ, 1992, p. 154). A função da consciência seria a de capacitar o home a adaptar-se ao meio ambiente. Ainda que numa abordagem mais contemporânea se defenda prioritariamente o conceito de acoplamento do sujeito ao meio e não de sua adaptação, a construção do ser se dá pela apreensão do saber.

Quando ocorre uma interação com o meio e o sujeito, podemos considerar como verdadeiro que alguma emoção será produzida. De acordo com Rocha (2009), a emoção humana é considerada um sinal de descontrole, quando o instinto e a irracionalidade são ativados. Porém, a autora ressalta que as emoções, quando conduzidas pela inteligência num ato intencional, tornam-se uma interface para a apreensão do conhecimento. Podemos complementar a importância do estímulo da emoção no processo de apreensão do conhecimento com o que foi apresentado por Varela, onde a cognição atua além do campo mental e simbólico e envolve uma experiência corporal como um todo.

Um dos princípios na ergonomia cognitiva aplicável ao projeto gráfico é a redundância. Outro princípio é o nível de socialização de uma informação. Tentaremos compreender estes princípios a seguir.

Niemeyer (2009) afirma que, em qualquer projeto de design, faz-se necessário considerar que tipo de percepção o usuário terá ao entrar em contato com um determinado produto, ou seja, deve-se prever como o usuário irá interagir com o objeto criado. Assim, é importante que o projeto de um produto ou de um sistema gráfico considere que as partes constituintes desse produto atuem como elementos de linguagem produzindo subjetividades para o con- sumidor, empregando formas, cores, texturas e materiais.

Moraes (2002) explica que, no processo de comunicação, o receptor da mensagem (consumidor) precisa recebê-la, o que exige a seguinte sequência de fenômenos psico-sociológicos:

- a atenção, dependente do estado de alerta e da qualidade do ambiente onde o receptor está inserido;

- percepção: dependente do processo realizado no entro do contexto cultural onde o receptor está inserido;

- compreensão: envolvendo uma correspondência entre o que a fonte da mensagem (rótulo) pretendia informar e o que o receptor da mensagem (consumidor) compreendeu da mensagem recebida;

- memorização ou retenção seletiva da mensagem por parte do receptor (consumidor).

Moraes ressalta que a compreensão da mensagem não é suficiente para a sua aceitação, não sendo sequer condição necessária para isso. Uma mudança de atitude estimulada por algum tipo de informação comunicacional exige a combinação do que ela chama de universo tridimensional, abrangendo a dimensão cognitiva (as opiniões sobre as quais a mensagem se fixará), a dimensão afetiva (o grau de confiança que o consumidor deposita na mensagem recebida) e a dimensão conotativa (a intenção de ação do consumidor). Moraes lembra que o receptor da mensagem (consumidor) é um indivíduo que vê o mundo sob seus próprios filtros perceptivos. Assim, aquele que deseja comunicar algo, deve compreender que um objeto qualquer é o meio pelo qual uma informação é transmitida. Faz-se necessário que se compartilhe entre o transmissor e o re- 
ceptor as mesmas condições de individuação. Por isso, outros fatores precisam ser abordados para compreendermos como se processa a percepção de uma informação. A modelagem comunicacional tende para o que Kincaid (apud MORAES, 2002) chama de modelo de convergência. Kincaid aponta que, quando a informação é partilhada por dois ou mais indivíduos, o processamento da informação deve conduzir à entendimento mútuo, à concordância mútua e à ação coletiva de subjetivação. Na filosofia, tal entendimento do processamento de informações remete à idéia de comum e de plano de imanência. Verificamos assim a construção de uma noção convergente ao que o filósofo Ulpiano irá classificar de "opinião", como algo que existe num plano mental coletivo que ele chama de "doxa". No modelo de convergência, existem três níveis de realidade: física, psicológica e social. Moraes (2002) explica que, no modelo de convergência, a comunicação é um processo no qual os participantes compartilham informações, de modo a criarem um suficiente nível de entendimento mútuo. É este entendimento coletivo que Ulpiano (1994) irá classificar como doxa. Além disso, o processo de comunicação sofre constante retro-alimentação em todas as suas fases. Segundo a autora, a memorização de um símbolo será proporcional à simplicidade e objetividade com as quais este foi desenvolvido, ressaltando a importância do emprego de sistemas que tenham como recurso o uso do conhecimento prévio (cultura) do receptor (consumidor). Nesse caso, a utilização de pictogramas e mensagens de fácil entendimento, ou seja, o aproveitamento do conhecimento pré-existente do consumidor é fator de incremento na eficácia de um projeto gráfico.

Para compreendermos a influência subjetiva da forma, é preciso determinar como ocorre a percepção da forma e como a mente humana entende e interpreta a imagem. De acordo com Niemeyer (2009), a percepção de um produto dependerá do julgamento a que este for submetido. Daí, face à sua estrutura mental, o indivíduo reage a esse produto, ou seja, trata-se aqui, de construir modos de subjetividade neste consumidor. Este é um campo investigado por estudos em semiótica. Niemeyer (2009) define semiótica como a teoria geral dos signos, que é o mediador entre algo ausente e como este é percebido pelo intérprete presente. Nöth (1995) define semiótica como a ciência dos signos e dos processos significativos na natureza e na cultura.

Em termos de análise e percepção da forma, temos a representação pictórica como o signo. O signo é percebido sensorialmente pelo intérprete (consumidor, usuário, espectador) que processa mentalmente a informação recebida, compara-a consciente e inconscientemente com seus parâmetros culturais e afetivos, respondendo e reagindo à interpretação processada.

Para Nöth (1995), no século XVIII, focava-se a análise de três aspectos na semiótica: a anamnese, a diagnose e a prognose. A anamnese significa analisar a absorção das informações históricas, conceituais e culturais do objeto observado. A diagnose compreende a comparação dos dados observados na anamnese com base em conhecimentos anteriores. A prognose implica na formatação dos resultados obtidos a partir da diagnose e da anamnese. A autora destaca o modelo platônico na observação dos objetos, onde o símbolo era composto por três elementos: o nome, a idéia e a coisa ou objeto material. Nöth (1995) destaca que é durante a Idade Média que a semiótica assume um escopo de ciência da lógica da percepção e cita o filósofo Leonino de Pádua que afirma que 
a lógica é a doutrina principal dos signos. Pelo menos, assim era o entendimento da semiótica ainda no início da Renascença, e é possível que tal conceito possa ter influenciado Rafael em seu processo criativo.

Em termos de percepção da forma, a semiótica aborda uma relação triangular que envolve o interprete, o objeto imediato ou a forma e o signo. $O$ intérprete é o consumidor ou o espectador. É aquele que percebe a forma. $\mathrm{O}$ objeto ou forma é aquilo que é percebido. $O$ signo em si é o modo como o fenômeno é percebido. De acordo com Niemeyer (2009), toda imagem traz uma mensagem que não inocente. Toda mensagem possui uma carga de informação que é composta por dois componentes: persuasão e manipulação. Persuasão é a estratégia para fazer o intérprete crer em algo. Manipulação é a estratégia utilizada para promover no intérprete uma reação. Novamente, o que observamos, é a manifestação de um processo de construção da subjetividade por meio da informação. Observamos o objeto real (exterior ao sujeito) construído num processo de individuação que passa a ser apreendido pelo sujeito de forma análoga à individuação de seu conhecimento. ${ }^{5}$

\section{A psicologia, a filosofia e a arte}

Eis-me portanto em presença de imagens, no sentido mais vago em que se possa tomar essa palavra, imagens percebidas quando abro meus sentidos, despercebidas quando os fecho. Todas essas imagens agem e reagem umas sobre as outras em todas as suas partes elementares segundo leis constantes, que chamo leis da natureza, e, como a ciência perfeita dessas leis permitiria certamente calcular e prever o que se passará em cada

\footnotetext{
${ }^{5}$ Adaptado de "A Gênese do Indivíduo", Simondon (2003).
}

uma de tais imagens, o futuro das imagens deve estar contido em seu presente e a elas nada acrescentar de novo. No entanto há uma que prevalece sobre as demais na medida em que a conheço não apenas de fora, mediante percepções, mas também de dentro, mediante afecções: é meu corpo (BERGSON, 1939).

Então, a arte é uma expressão. Expressão de quê? Expressão desses mundos possíveis, expressão dessas essências (ULPIANO, 1994).

Gilles Deleuze e Félix Guattari foram autores que dedicaram estudos sobre a psicologia e a filosofia da forma e das imagens. Deleuze e Guattari (1992) trazem à luz dois conceitos novos, mas que são convergentes a abordagem apresentada neste artigo: $O$ afecto e o percepto.

Para desenvolver sua análise sobre estas duas novas definições, os autores utilizarão a arte como cinzel. A arte será a palheta para ilustrar nossa própria composição, aquilo do qual somos feitos, no tempo, no espaço e em movimento. Todos os dias que passam, sobrepomos mais tinta sobre a paisagem que construímos de nós mesmos. A cada momento, mais uma nota é acrescentada em nossa harmonia. A cada acontecimento, mais uma lasca é arrancada de nosso bruto mármore ou mais uma palavra é acrescentada em nossa biografia.

Deleuze descreve, por exemplo, que a pose da moça retratada na escultura guarda o gesto que independe de quem o fez e das ferramentas empregadas, mas preserva uma potência intencional de sensações capazes de serem percebidas e de afetar naqueles que a observam. De forma que os perceptos e os afectos não são mais percepções ou afecções, mas a potência de provocar algo de diferente, que é mutável e individual, ou melhor, subjetivo naquele que observa. "O percepto é a paisagem 
anterior ao homem, na ausência do homem" (DELEUZE; GUATTARI, 1992). Os autores definem que o percepto é a capacidade imanente de tornar sensíveis as forças insensíveis que povoam o mundo, e que nos afetam, nos fazem devir. Assim, podemos entender o percepto como força ou potência de transformar, de tornar alguém em algo, movimentando como um motor o devir humano. Tal ideia se sustenta, embora com fundamentos diversos, nos conceitos de essência em Proust, Platão e nos Estóicos ${ }^{6}$. De acordo com Ulpiano (1994), a essência é uma propriedade do objeto que é fora do tempo, ela teria eternidade. É importante compreendermos que essa potencialidade de subjetivar presente na obra não se restringe a alguém específico, mas tem como objetivo afetar a qualquer um, uma vez que é da ordem do impessoal, e que coexiste como comum no homem inserido em uma sociedade. Esses conceitos complementam a noção de percepção e de afecção apresentadas por Bergson e são importantes para compreendermos alguns aspectos no método de trabalho desenvolvido por Rafael Sanzio, como veremos mais adiante.

Para Deleuze e Guattari os artefatos estão carregados de perceptos e de afectos, independente de se atingir ou não a perfeição, mas da carga de intenção expressiva que o artista imprime em sua obra. A segunda metade do século XIX e o século XX trazem este entendimento nas artes. A potencialidade de afetar e de perceber algo na obra transcende sua verossimilhança. Em seu texto, Deleuze parece apontar que este foi o berço em que a arte moderna floresceu. Por outro lado, a obra humana como um todo é igualmente rica de afectos e perceptos, e, de certa forma, pretendemos apresentar isso mais adiante, quando analisarmos a obra de Rafael Sanzio.

\footnotetext{
$\overline{{ }^{6} \text { Claudio Ulpiano, } 1994 .}$
}

A mente humana pode organizar sentidos mesmo quando eles não existem intencionalmente: quando percebemos formas em cadeias de montanhas, ou em aglomerados de estrelas. De forma que uma tela de um único azul pode estar carregada de potências que podem provocar inúmeras emoções em um observador e gerar total indiferença em outro. A tela azul não é mais ou menos bela por isso; um observador não será mais ou menos sábio por isso. Deleuze e Guattari (1992) destacam os vazios que toda obra deve conter: "... mas algo só é uma obra de arte se, como diz o pintor chinês (HUANG PIN-HUNG), guarda vazios suficientes para permitir que neles saltem cavalos". A obra de arte deve permitir este nível de comunicação entre o criador e o observador. Segundo os autores, a arte tem como objetivo arrancar o percepto das percepções do objeto e arrancar os afectos das afecções do sujeito, onde, ainda que sob a corrosão do tempo, seja imortal enquanto persista a existência de seu suporte material. Eles descrevem o artista como um criador ou inventor de afectos, aquele que é capaz de trazer a nós os afectos, transformando-nos com sua obra. Isso significa saltar para fora de um ego e manifestar o impessoal na obra, para que se possa atingir a qualquer um. Devemos, então, perguntar: quais são os motivos contidos na obra? Ao encontrarmos os motivos, encontraremos os perceptos. Uma paisagem pode conter algo a mais do que a representação de um panorama estático? Se sim, isso é percepto. A eternidade de uma obra permanece enquanto esta arde em propósitos, assumindo vida própria. Nas palavras de Ulpiano,

[...] o homem seria dotado de pensamento, mas o pensamento dele seria para apreender as essências. Então, enquanto o sujeito humano discutisse sobre os objetos, ele viveria 
no campo da "doxa"7, no campo das opiniões. E para atingir as essências, ele teria que abandonar a "doxa" e entrar na episteme. A episteme é o pensamento [...] (ULPIANO, 1994).

Como veremos mais adiante, Rafael Sanzio parece praticar a episteme da arte em sua obra, embora articule esta episteme como artifício para construir uma opinião (doxa) nas massas. Por outro lado, seja na episteme, seja na doxa, os perceptos e os afectos guardam certa relação de dependência com o observador, pois a potência de afetar e de perceber sofre influência do grau de significação que determinado aspecto apresenta para este sujeito. Esta significação depende da existência de códigos anteriores, ou seja, depende de elementos de memória no sujeito, que são, inclusive, transitórios e mutáveis no tempo. Nas palavras de Simondon:

O indivíduo que vive é contemporâneo de si mesmo em todos os seus elementos, o que não ocorre no indivíduo físico que contem um passado radicalmente passado, inclusive se está, todavia, em um processo de crescimento... (SIMONDON apud SANTAMARIA 2006) [Tradução do autor].

\section{A neurociência e o uso da tecno- logia na compreensão do compor- tamento humano}

A primeira impressão é a que fica. De acordo com estudos de Lindgaard et al. (2006) após a realização de testes de usabilidade em sítios eletrônicos, verificou-se que a atratividade emocional percebida no design desses sítios

\footnotetext{
7 Doxa é um termo de origem grega no qual o fundamento de um argumento se dá pelo senso comum. Nesse sentido a doxa se opõe à episteme, ou saber verdadeiro.
}

influenciava mais que sua qualidade ergonômica. Isto significa que o apelo visual pode ser o fator prioritário na escolha e manutenção do interesse de um usuário web, em declínio da usabilidade. Os autores apontam que a velocidade de percepção interesse do usuário é de algo entre 1 a 5 milissegundos. Estudos neurológicos recentes indicam que um organismo reage e reconhece afetivamente um estímulo antes que possa agir cognitivamente por meio da razão, ou melhor, analisar e avaliar racionalmente a percepção desses estímulos (DAMASIO, 2000). A noção de que as propriedades emocionais de um objeto são percebidas pela mente numa fração de segundos instiga em outro tipo de indagação: o que desperta o interesse humano? A pesquisa do comportamento focada no padrão de movimento dos olhos (eyetracking ${ }^{8}$ ) e do comportamento pupilar procura obter respostas nas últimas décadas, determinando métodos para reconhecer o que afeta o sujeito para, a partir deste conhecimento, encontrar formas de fabricar a subjetivação no consumidor.

A técnica do eyetracking vem sendo aplicada em análises da clínica do trabalho, no desenvolvimento de peças publicitárias, no mapeamento das áreas de maior relevância para a exposição de produtos em gôndolas ${ }^{9}$ de supermercados e no projeto de sítios eletrônicos, entre ouras. De acordo com Ewing (2008), esta tecnologia oferece uma forma objetiva para localizar o foco de atenção de um indivíduo em um determinado cenário. Algumas empresas oferecem em seus sistemas a capacidade de analisar também o comportamento da pupila nos usuários. Isso permite identificar

\footnotetext{
${ }^{8}$ Ver mais detalhes nos artigos: An Eye Tracking Study on the Effects of Layout in Understanding the Role of Design Patterns. ${ }^{9}$ Strunck (2001): 85\% das compras de todos os produtos disponíveis em supermercados no Brasil se concretiza no ponto de venda. Por isso, o interesse pela escolha das cores e a disputa por espaço de exposição.
} 
o que o usuário priorizou observar e como isso o afetou. Estudos de Hess e Polt (1960 e 1964) relacionam o nível de interesse e a atividade mental com o comportamento do diâmetro pupilar em voluntários.

Outing e Ruel (2004) avaliaram preferências de usuários em contato com a página inicial de um sito eletrônico usando a técnica do eyetracking. Os pesquisadores notaram que os usuários fixam seu olhar inicialmente no canto superior esquerdo da página web para depois realizar uma varredura para a direita e para baixo. Este padrão de comportamento é convergente com o que foi observado por Ostrowner (1983) em seus estudos. As Figuras $1 \mathrm{e}$ 2 a seguir ilustram os resultados apresentados pelos pesquisadores.

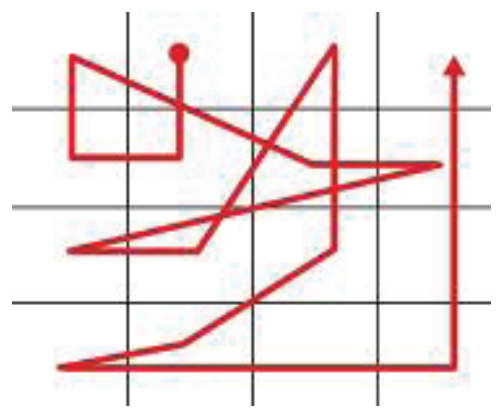

Figura 1. Traçado a partir do olhar de um usuário Fonte: Adaptado de Outing e Ruel (2004).

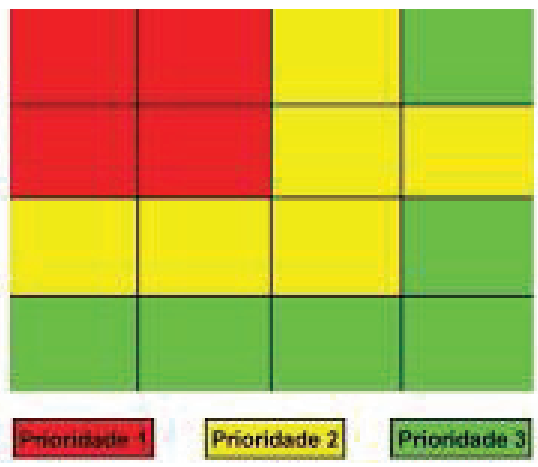

Figura 2. Zonas de prioridade preferencial de usuários Fonte: Adaptado de Outing e Ruel (2004)
A zona vermelha representada na Figura 2 é a região mais observada. Convencionou-se a coloração vermelha para identificar sua relevância. Essas áreas são denominadas pontos de atenção ou hot spots.

Gil (2000) destaca que a construção do sujeito ocorre principalmente a partir daquilo que ele vê. É na visão humana que o objeto qualquer assume sua singularidade. Gil questiona sobre como um objeto se torna relevante para alguém sem fragmentar sua visão num cenário de objetos diferenciados e potencialmente significantes. O autor sugere que a diferenciação se manifesta pelo afeto que dado objeto provoca em seu observador. Essa capacidade pode ser modulada a partir do quanto o projetista do objeto ${ }^{10}$ produz maior ou menor singularidade no mesmo. Um projeto de gráfico implica dividir e fragmentar o espaço, diferenciando suas partes. Gil (2000) indaga sobre quais transformações o pensamento e a sensação devem sofrer para que a percepção apreenda um objeto ao mesmo tempo singular e objetivo. Responder a esta questão é um objetivo compartiIhado pelas pesquisas dedicadas ao estudo do comportamento da visão.

A análise de comportamento aponta que é possível prever e controlar o interesse dos usuários, ou seja, é possível fabricar modos de subjetividade.

Com relação à análise representativa na obra de Rafael, o que podemos observar é a caracterização de um processo de individuação engendrado em um sistema de elementos pictóricos cuja motivação é muito convergente às singularidades descritas por Gil.

Simondon (2003) define a individuação como a resolução parcial e relativa, que se ma-

\footnotetext{
${ }^{10}$ Quando Gil (2000) se refere a um objeto, o autor não aborda apenas aqueles que são desenvolvidos pelo homem, mas qualquer tipo de objeto.
} 
nifesta em um sistema que contém potenciais e encerra certa incompatibilidade em relação a si próprio, incompatibilidade feita tanto de forças de tensão como de impossibilidade de uma interação entre termos extremos das dimensões. Por outro lado, como veremos mais adiante, a presença de forças de tensão em cada objeto singular escolhido e posicionado no espaço da tela pelo artista, se articula justamente como o elemento de interação em todas as direções dimensionais da obra. No entanto, como o propósito de Rafael parece ser informar algo, tal interação não se traduz em passividade, mas em conflito, concebido com o propósito de produzir dentro do sistema espectador/tela uma experiência de descoberta.

O mesmo método pode ser empregado para explorar a afetividade e a emotividade, que constituem a ressonância do ser em relação a si próprio e ligam o indivíduo à realidade pré-individual que the é associada, como a unidade tropística e a percepção o ligam ao meio (SIMONDON, 2003).

Simondon (2003) define informação como o início da individuação, pois a informação supõe tensão de um sistema do ser, que é inerente a uma problemática e, por isso, apresenta uma dimensão organizadora produzindo no indivíduo o efeito da descoberta.

\section{0 método de projeto em Rafael}

\section{Sanzio}

A obra de Rafael Sanzio caracteriza-se pela religiosidade, tanto nas gravuras, como nas pinturas e na arquitetura. Tal religiosidade guarda mais relação com interesses sociais e financeiros do artista do que com motivações espirituais. Hauser (1972) descreve que Ra- fael, como outros artistas renascentistas, era proprietário de palácios, contemplado com títulos de nobreza e via a Igreja como principal financiadora. A influência da Igreja na obra de Rafael é um aspecto que pode ser reconhecido comparando as temáticas de suas pinturas com seus estudos pessoas. Enquanto identificamos certa serenidade nas poses e composições nas obras encomendadas pela Igreja, seus estudos anatômicos pessoais, por outro lado, apresentam grande energia muscular e dinâmica com as quais o autor expressa sua verdadeira manifestação criativa e pessoal.

Sua biografia indica que o artista foi preferencialmente influenciado por Fra Bartolomeu, Miguelangelo e Leonardo Da Vinci. A influência de Leonardo na obra de Rafael é documentada por biógrafos como Thoenes (2005). Esta fase de seu processo criativo é conhecida como período florentino. Rafael levou uma vida nômade, mas foi em Florença $(1504)^{11}$ que se fixou por mais tempo. Tanto a influência de Leonardo na composição estrutural dos arranjos como a influência do próprio contexto renascentista pode ter conduzido Rafael Sanzio a incorporar em sua obra as relações de proporção na seção áurea, o que tentaremos demonstrar a seguir. A presença da geometrização do espaço e o emprego da seção áurea se fundamenta por Rafael ter sido também arquiteto.

Não pretendemos reivindicar a primazia por identificar o uso da proporção áurea na obra de Rafael, mas pretendemos demonstrar a possibilidade de outros tipos de abordagem.

A Figura 3 apresenta uma gravura feita por Joseph Mallord William Turner, Turner (1810) foi possivelmente o primeiro a identificar relações de geometrização baseadas na proporção áurea no quadro A Transfiguração, de Rafael.

\footnotetext{
${ }^{11}$ Período em que Leonardo Da Vinci ainda vivia em Florença.
} 


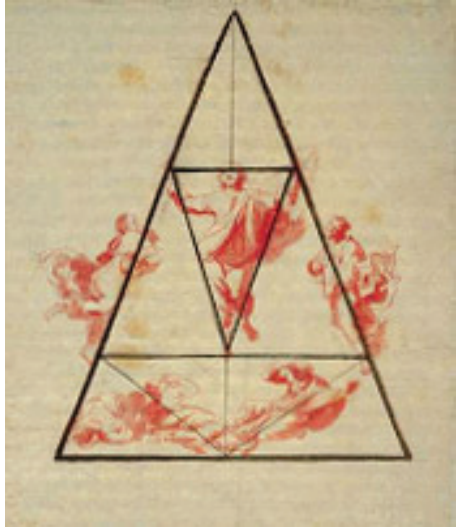

Figura 3. O uso da proporção áurea no quadro "A Transfiguração", Estudo realizado por Truner em 1810.

Fonte: www.tate.org.uk

Pelo este diagrama, evidencia-se que Rafael organizava o arranjo espacial e com o posicionamento dos elementos pictóricos. Neste diagrama identificamos a determinação deliberada em não apenas organizar o espaço, mas de construir uma estrutura de subdivisões que guardam relações de proporcionalidade e interação, especificamente orientadas pela seção áurea. Verificamos ainda que existe um ciclo conduzindo o olhar do observador. Isto representa a manifestação de modos de subjetividade através de um regime de visibilidade. Cada personagem principal desenvolve elos numa corrente rítmica que conduz o observador retornando sua atenção ao objeto principal de toda a imagem: o Redentor. A presença desse ciclo é indício de que Rafael sabia como conduzir a atenção de seu público. Exclui-se seu empirismo pela presença de uma sequência pictórica lógica, evidência de que Rafael conhecia a semiótica como ciência dos signos. Que outros cavalos de Huang Pin-Hung encontraremos nesta obra e como se chegou a tais resultados? Observemos na Figura 4 a seguir.

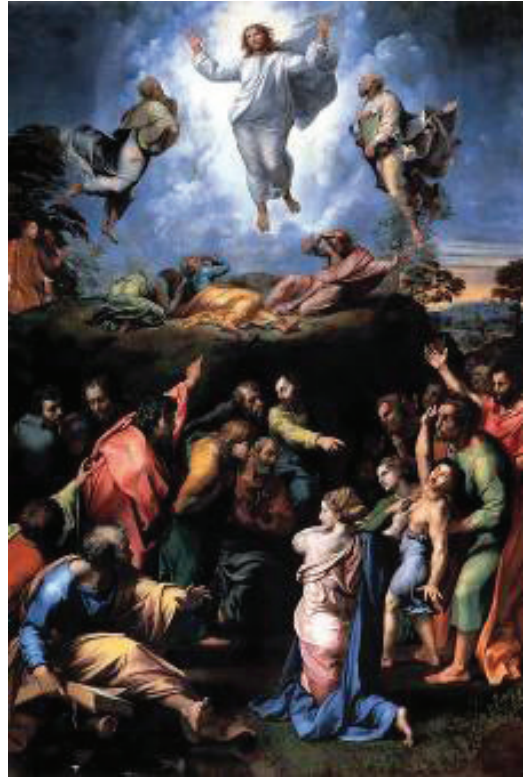

Figura 4. A Transfiguração de Rafael Sanzio, 1520

Desconstruiremos este quadro para desenvolver uma análise isolando os principais personagens que o contextualizam. Rafael inicia seu desenvolvimento posicionando sua representação de Cristo centralizada no eixo horizontal da tela, pouco acima do centro geométrico. Esta representação é da com a tendência artística da alta renascença, quando o pranto e a dor gótica não encontra mais amparo, e o Cristo já não é mais o mártir crucificado, de outra sorte, é representado vivo e glorioso. Esta escolha espacial converge com a área nobre da tela descrita por Ostrowner e apresenta uma roupagem simbólica em sintonia com a carga representacional de sua época como definido por Hauser. Com isso, Rafael estabelece o seu ponto principal de atenção e define um eixo de simetria em seu projeto. 


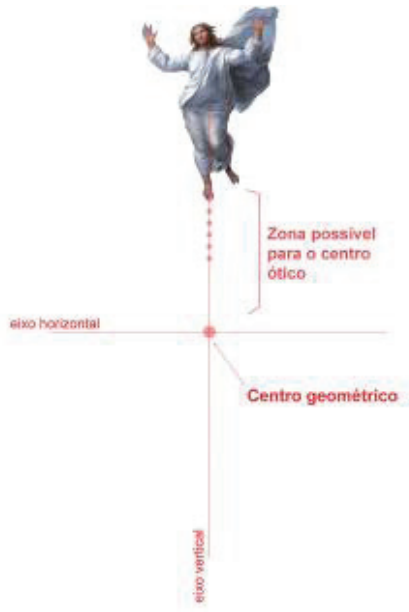

Figura 5. Processo construtivo na arte de Rafael

Em seguida, Rafael distribui de forma simétrica os personagens da história que narra sua tela, como vemos nas Figuras 6 e 7. Podemos observar também o surgimento de linhas oblíquas a esquerda e a direita do eixo vertical central, assim como grifou Turner em seu diagrama. Tais linhas "imaginárias" formam um conjunto que proporciona no espectador a percepção do movimento na cena e conduzem a mente deste observador, como descrito por Ostrowner. Verificamos aqui as três funções básicas da forma apontadas por Wong: a representação, o significado e a função. Cada elemento pictórico conduz ao seguinte num arranjo que se materializa em algo novo, num processo de individuação: a própria tela em si. De acordo com Simondon (2009), para que uma individuação se efetue no sujeito, é preciso que ocorra a transformação de um sistema em algo novo, que seja organizado. E é esta organização sistêmica que percebemos se desenvolvendo.

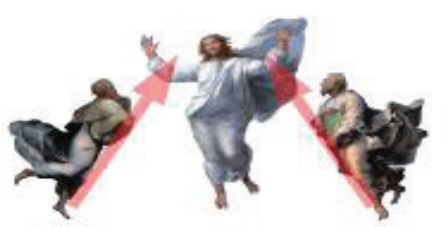

Figura 6. Processo construtivo na arte de Rafael

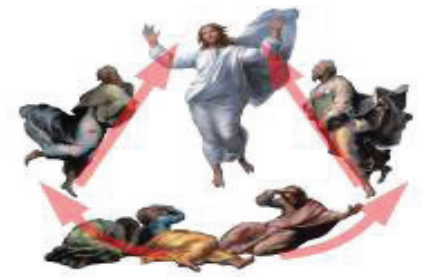

Figura 7. Processo construtivo na arte de Rafael

Embora o quadro seja conhecido como A Transfiguração, este se divide em duas cenas. A primeira representa a cura do mancebo do qual Cristo expulsa uma legião de demônios. Esta cena ocorre nos dois quadrantes inferiores e a segunda cena, a da transfiguração, nos dois quadrantes superiores. É importante observar que Rafael trabalha sua comunicação com signos conhecidos por seu público em seu tempo, são duas cenas consecutivas com passagens Bíblicas. Nem sempre Rafael usará este tipo de artifício em sua arte. Por exemplo, na obra Escola de Atenas, os personagens e os signos ali desenvolvidos apresentam pouco ou nenhum significado para as massas ou para o homem inculto ${ }^{12}$, diferente do que ocorre no quadro A Transfiguração. Aqui Rafael emprega conceitos da comunicação e da semiótica, como vimos em Niemeyer e em Nöth.

A arte $^{13}$ emancipa-se dos dogmas eclesiásticos, mas fica intimamente relacionada com

\footnotetext{
12 Como apontado por Hauser (1972).

${ }^{13}$ Hauser se refere à arte renascentista ao escrever esta citação. De acordo com HAUSER, a uniformidade e a consistência espacial foram os critérios mais elevados no processo criativo dos artistas entre 1500 a 1900 , o que o historiador chama de cientificismo organicista na arte.
} 
a filosofia científica da época... (HAUSER, 1972).

Rafael elabora as inter-relações nos elementos pictóricos das duas narrativas representadas. Sempre respeitando a simetria, inclusive no emprego das cores e nas relações de figura e fundo. Podemos encontrar grande convergência do método de trabalho de Rafael com as palavras de Bergson (1939):

[...] imagens agem e reagem umas sobre as outras em todas as suas partes elementares segundo leis constantes, que chamo leis da natureza, e, como a ciência perfeita dessas leis permitiria certamente calcular e prever o que se passará em cada uma de tais imagens $[\ldots]$.

Com isso, Rafael introduz um elemento que podemos classificar como identidade visual e aplica princípios de forma e desenho como descritos por Wong, Munari e Ostrowner, como podemos observar na Figura 8. Através da exploração desta imagem, podemos perceber que ocorre a mesma noção cíclica de controle do movimento do olhar em ambas as cenas, a cena da transfiguração e a cena da cura do mancebo, onde cada personagem dialoga em gestos e em linguagem corporal com o seguinte e todos apontam novamente para o Cristo. Rafael usou este recurso para captura e controle de seu público-alvo.

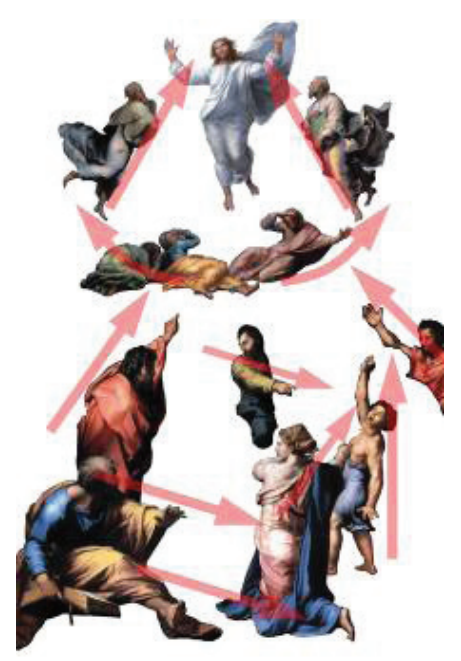

Figura 8. Processo construtivo na arte de Rafael

Como Rafael obteve este efeito? Como o artista imprimiu este controle geométrico em sua obra? O diagrama de Turner nos aponta uma direção. Neste diagrama podemos observar a construção de uma grade simples, um rudimentar sistema de rede, onde podemos verificar um grande triângulo isósceles que é formado por outros dois triângulos menores, alinhados segundo o eixo vertical principal. Esses triângulos estão na proporção áurea e suas subdivisões também são formadas por triângulos nesta proporção. Elam, Doczi e Ostrowner apresentam construções semelhantes nas obras de diversos artistas na história da arte. Porém, seria possível encontrar uma relação de seção áurea nas duas cenas? A primeira cena apresenta um possível problema. O personagem principal da primeira cena é o mancebo, que está em posição vertical. Nenhuma parte de seu corpo parece sugerir intuitivamente a existência de linhas diagonais imaginárias nas quais possamos encaixar um triângulo de seção áurea segundo a ordem percebida por Turner na segunda cena. No entanto, Alberti (1485, apud HAUSER, 1972) afirma que a obra de arte 
é constituída de tal maneira que é impossível tirar-lhe ou acrescentar-lhe algo sem desequilibrar a beleza do todo. Então, deve existir uma relação geométrica que estabeleça a correspondência entre as duas cenas. Este é um indício de que talvez seja necessário imaginar outro modelo de malha, que não o proposto por Turner. Na figura 4, podemos verificar que o contexto desta imagem é muito mais denso de elementos pictóricos do que podemos verificar no diagrama de Turner. Esta multiplicidade é característica na representação pictórica de Rafael. Sua biografia sugere que o autor foi imprimindo um estilo diferenciado quando comparado a outros artistas de seu tempo. $\mathrm{Na}$ figura 8, podemos identificar evidências de que Rafael se preocupou em ordenar a geometrização espacial de diversos elementos gráficos, nos quais todos se relacionam. Teria o pintor organizado o posicionamento de outros elementos presentes na imagem, ou se concentrou apenas nos personagens principais? Se a resposta for positiva, como Rafael desenvolveu esta estrutura?

Simondon (2003) define que a noção de forma deve ser substituída pelo conceito de informação, a qual pressupõe a existência de um sistema em estado de equilíbrio metaestável. Esta passagem entre a forma e a informação é o que encontraremos na obra de Rafael. O que percebemos, ao analisar a tela de Rafael, é que parece existir um outro padrão de linhas oblíquas simétricas e alinhadas segundo o eixo vertical horizontal. Este padrão pode ser identificado na imagem e forma um sistema de rede denso que define o posicionamento de cada elemento pictórico na pintura, ou seja, Rafael desenvolveu uma mancha gráfica em sistema de redes em 1520.

O conceito de malha ou rede também pode ser enunciado no que Simondon (2003) define como transdução - uma multidão de aspectos organizados. Para o autor, a transdução é uma operação mental (entre outras descritas) pela qual uma atividade se propaga gradativamente no interior de um domínio, fundando esta propagação sobre uma estruturação do domínio operada de região para região: cada região de estrutura constituída serve de princípio de constituição à região seguinte, de modo que uma modificação se estende progressivamente ao mesmo tempo que esta operação estruturante. O autor ainda destaca que a transdução sempre ocorre quando há atividade estrutural e funcional a partir de um centro do ser e se propagando para várias direções, como se houvesse múltiplas dimensões desse ser entorno do mesmo.

A rede encontrada na tela apresenta certo conjunto de propriedades de rede como descritas por Wong. Entre elas, a rotação, a reflexão e a simetria com relação ao eixo vertical. Ao verificarmos as proporções das áreas formadas pelo padrão desenvolvido, identificamos que cada célula da rede estava na proporção áurea. Podemos observar seu sistema de malhas na Figura 9 a seguir.

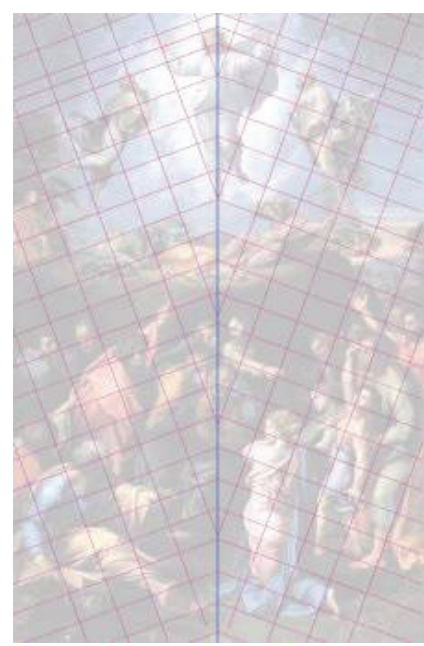

Figura 9. Sistema de rede identificado no quadro "A Transfiguração de Rafael" 
Na Figura 9, podemos verificar que o quadril da moça de amarelo, posicionada à direita apontando para o mancebo alinha-se com o olho direito no rosto do homem entre a moça e o mancebo, e o eixo médio do rosto do mancebo se alinha com o olho esquerdo do outro personagem que segura-o por traz. Encontraremos simetricamente no eixo esquerdo, alinhamentos da mesma natureza compondo a rede. Podemos seguir com este detalhamento, identificando cada elemento que compõe a figura, mas o que importante investigar a partir deste ponto da análise é se esta aplicação estiver correta, existe relação geométrica entre a rede descrita em nosso estudo e o diagrama de Turner? Observemos a Figura 10.

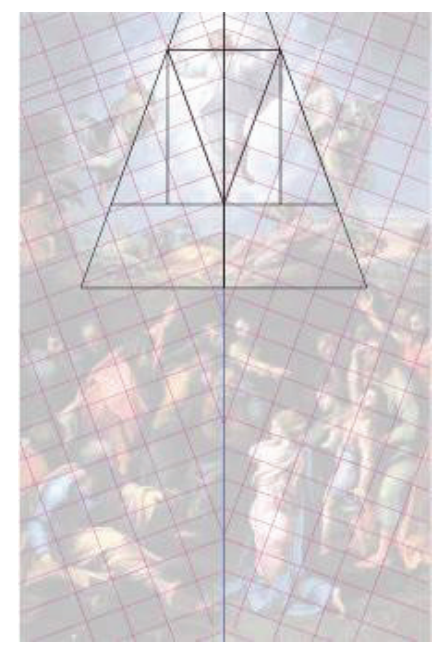

Figura 10. Relação entre o diagrama de Turner e a rede proposta

A Figura 10 apresenta uma sobreposição do diagrama de Turner sobre a rede áurea aqui proposta. Verificamos total acoplamento nas duas abordagens, porque nosso achado é um desdobramento do diagrama de Turner. Ao se fragmentar o espaço em triângulos áureos cada vez menores continuamente, desenvolve-se uma rede que se sobrepõe à nossa proposta. Tal associação evidencia a busca por organizar a correspondência entre as duas cenas. Como já vimos, esta obra é carregada significados nos elementos gráficos, nos levando a questionar se o sistema de rede aqui demonstrado levantaria outras possibilidades presentes.

Retornando à Figura 9, verificamos que é possível traçar eixos verticais e horizontais sobre a representação de Cristo, compondo uma cruz áurea como observamos na Figura 11.

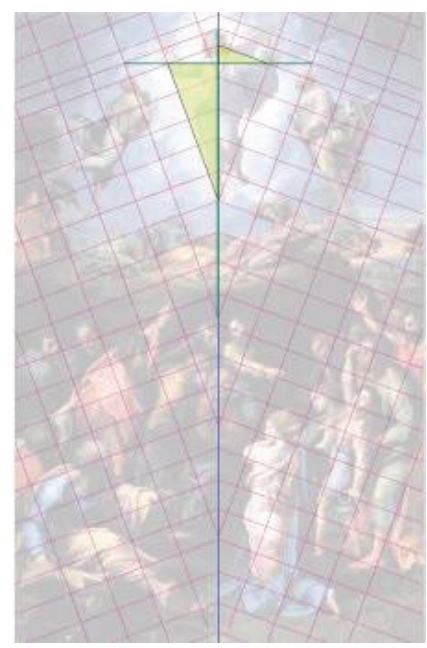

Figura 11. A presença de uma cruz áurea

A proporção áurea traz uma carga cultural histórica de relação com o Sagrado, com o Divino. Nesta, a presença deste signo na estrutura de geometrização é significativamente simbólica, aliando o Sagrado à imagem de Cristo através de um recurso geométrico: a proporção áurea. Segundo Vitruvius:

Para que os templos fossem magnificentes, deveriam ser construídos tendo por base a analogia do corpo humano bem formado, no qual existe uma harmonia perfeita entre as partes (Apud DOCZI, 1981). 
Esta harmonia perfeita entre as partes no corpo humano bem formado tinha como base a seção áurea. O que resulta a sobreposição do Homem Vitruviano sobre a Transfiguração de Rafael? Veremos isso na Figura 12 a seguir.

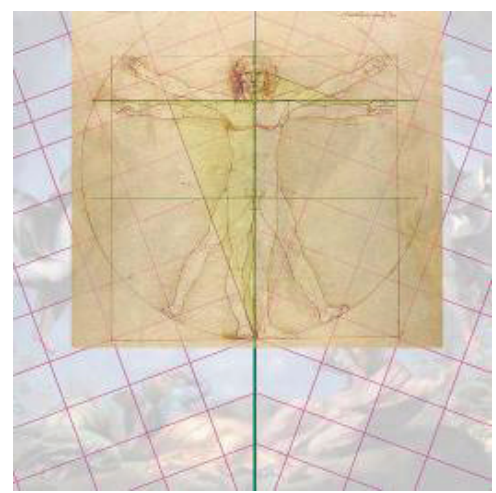

Figura 12. Sobreposição do Homem Vitruviano na rede proposta

Aqui identificamos um signo de religiosidade no projeto de Rafael remetendo à sua influência a partir da obra de Leonardo Da Vinci: O Cristo representado soberano, associado a uma subjetiva cruz áurea que não é aparente, mas latente, signo do próprio Redentor e signo da harmonia e da perfeição anatômica, cujo
Corpo deveria ser representado proporcional e perfeito.

\section{Conclusão}

A presença de um sistema de redes no trabalho de Rafael Sanzio e suas conexões simbólicas significa mero achado técnico. Identificamos uma metodologia na qual se manifesta o intencional no ato criativo no qual a arte pela arte não encontra identidade, mas o exercício intelectual e cientificista humano ordenando o caos, com o homem sendo parceiro do Criador na criação. O sistema de redes aqui representado é o desdobramento de nossa discussão: Rafael possuía uma metodologia aplicando conhecimentos do comportamento humano e organizava o espaço, planejava a integração das partes, construindo conscientemente processos de subjetivação. Podemos identificar os princípios fundamentais que hoje estabelecemos no desenvolvimento de um projeto gráfico e publicitário. Tudo isso é em si, algo extraordinário.

\section{Referências}

BECK, J. H. (1994). Raphael. Printed and bound in Japan: Thames and Hudson Ltd.

BERGSON, H. (1939). Matéria e Memória - Ensaio sobre a relação do corpo com o espírito. São Paulo, SP: Martins Fontes.

BRINGHURST, R. (2008). Elementos do Estilo Tipográfico. São Paulo, SP: Cosac Naify.

BROCKMAN, J. M. (1982) Sistemas de reticulas - Un manual para diseñadores graficos. BarceIona: Editorial Gustavo Gili.

CATÁLOGO da exposição Leonardo Da Vinci, a exibição de um gênio. CIE Brasil, São Paulo, 2007. 
DABNER, D. (2006). Guia de Artes Gráficas: Design e Layout. Barcelona: Editorial Gustavo Gili.

DAMAZIO, A. R. (2000). A second chance for emotion. Cognitive Neuroscience of Emotions. R. D. Lane and L. Nadel (Eds.). pg. 12-24, New York: Oxford University Press.

DELEUZE, G.; GuATtARI, F. (1992). O que é a Filosofia. Rio de Janeiro, RJ: Editora 34.

DOCZI, G. (2008). O Poder dos Limites. São Paulo, SP: Mercuryo.

ELAM, K. (2010). Geometria do Design. São Paulo, SP: Cosac Naify.

EWING, K. (2005). Studying web pages using Eye Tracking. Disponível em: http://pt.scribd.com/ doc/20321480/Tobii-Whitepaper-Studying-Web-Pages-Using-Eye-Tracking Acesso em: 10 jun. 2011.

FARINA, M. et al. (2006). Psicodinâmica das Cores em Comunicação. São Paulo, SP: Blucher Editora.

FRASER, T.; BANKS, A. (2007). O guia completo da cor. São Paulo, SP: Editora SENAC.

GIL, J. (2000). Diferença e Negação na Poesia de Fernando Pessoa. Rio de Janeiro, RJ: Relume Dumará.

HASLAM, A. (2007). O livro e o designer II: Como criar e produzir livros. São Paulo, SP: Edições Rosari Ltda.

HAUSER, A. (1972). História Social da Literatura e da Arte. São Paulo, SP: Editora Mestre Jou.

HESS, E. H. ; POLT, J. M. (1964). Pupil size in relation to mental activity during simple problem-solving. Science 143 , p. 1.190-2.

LINDGAARD, G. et al. Attention web designers: You have 50 milliseconds to make a good first impression! Disponível em: http://www.informaworld.com/smpp/content $\sim \mathrm{db}=$ all content=a727740369 Acesso em: 10 jun. 2011.

MEGGS, Philip B.; PURVIS, Alston W. (2009). História do Design Gráfico. São Paulo, SP: Cosac Naify. MONT'ALVÃO, C.; DAMAZIO, V. (2008). Design Ergonomia Emoção. Rio de Janeiro, RJ: 2AB.

MORAES, A.; MONT'ALVÃO, C. (2010). Ergonomia - Conceitos e Aplicações. Rio de Janeiro, RJ: $2 A B$. 
MUNARI, B. (2008). Das Coisas Nascem Coisas. São Paulo, SP: Martins Fontes.

NIEMEYER, L. (2006). Tipografia: Uma apresentação. Rio de Janeiro, RJ: 2AB. (2006). Elementos de Semiótica. Rio de Janeiro, RJ: 2AB.

NÖTH, W. (2005). Panorama da Semiótica - de Platão a Peirce. São Paulo, SP: Anablume.

OSTROWNER, F. (1991). Universos da Arte. Rio de Janeiro, RJ: Campus Editora.

OUTING, S.; RUEL, L. (2004). What We Saw When We Looked Through Their Eyes. Disponível em http://www.publetariat.com/sell/what-we-saw-when-we-looked-through-their-eyes Acesso em: 07 jun. 2011.

ROCHA, J. M. (2009). A Gênese Afetiva da Emoção e da Cognição na Consciência. Revista Informática na Educação: Teoria e Prática. Porto Alegre, RS: v.12, n.2, jul./dez. 2009. p. 93-104.

SANTAMARIA, J. W. M. (2006). La Individuación y la Técnica em la obra de Simondon. Colombia, Medelin: Fondo Editorial.

SCHULTZ, D.; SCHULTZ, S. E. (1992). História da psicologia moderna. São Paulo, SP: Cultrix.

SHARIF, B.; MALETIC, J. I. An Eye Tracking Study on the Effects of Layout in Understanding the Role of Design Patterns. Disponível em: http://www.cs.kent.edu/ jmaletic/papers/ICSM10-Sharif. pdf Acesso em: 10 jun. 2011.

SIMONDON, G. (2009). La individuación a la luz de las nociones de forma e información, Buenos Aires, Ediciones la Cebra y Editorial Cactus.

(2003). A Gênese do Indivíduo. In: O Reencantamento do Concreto. Cadernos de Subjetividade. Núcleo de Estudos de Subjetividade. Programa de Estudos Pós-Graduados em Psicologia Clínica da PUC-SP. São Paulo, SP: Editora Hucitec, p. 97-117.

STRUNCK, G. (2001). Como Criar Identidades Visuais Para Marcas de Sucesso. Rio de Janeiro, $\mathrm{RJ}: 2 \mathrm{AB}$.

THOENES, C. (2005). Raphael. Germany, Berlin: Taschen.

TONDREAU, B. (2009). Principios fundamentales de composición. Barcelona: Blume. 
WONG, W. (2010). Princípios de Forma e Desenho. São Paulo, SP: Martins Fontes.

\section{Sites:}

http://claudioulpiano.org.br.s87743.gridserver.com/?p=4908 Acesso em: 07 jun. 2011.

http://www.raphaelsanzio.org/biography.html Acesso em: 07 jun. 2011.

http://www.tate.org.uk Acesso em: 07 jun. 2011.

http://www.universalleonardo.org/ Acesso em: 07 jun. 2011.

Submetido para avaliação em 17 de julho de 2011.

Aprovado para publicação em 07 de novembro de 2013.

André Noronha Furtado de Mendonça: Designer gráfico; mestre em Design e Tecnologia - PGDesign; doutorando em Informática na Educação - UFRGS; bolsista CNPq na Universidade Federal do Rio Grande do Sul - Porto Alegre-RS - Brasil.

E-mail: andrefurtadodesigner@gmail.com

Tania Mara Galli Fonseca: Psicóloga, Doutora em Educação - UFRGS; professora dos Programas de Pós-Graduação em Psicologia social Institucional e Informática na Educação da Universidade Federal do Rio Grande do Sul. E-mail: tfonseca@via-rs.net 